\title{
IMAGES OF WAR IN GREECE AND ROME: BETWEEN MILITARY PRACTICE, PUBLIC MEMORY, AND CULTURAL SYMBOLISM*
}

\author{
By TONIO HÖLSCHER
}

(Plates I-VII)

\section{WHY WAR? WHY ART?}

Wars were once considered to be the essence of world history, but under the influence of social history, the histoire des mentalités, and the discourse of the 'cultural turn' their role has changed fundamentally. More interest is now paid to wars as part of cultural history than as highpoints of histoire événementielle.

Historians of the present generation stand in an ambivalent relation to the phenomenon of war. The 'cultural turn' in historical studies has generally focused on anthropological phenomena that are part of general human experience - love and death, body and soul, memory and hope, customs and emotions, mentality and ideologies. These phenomena, which are conceived as driving forces in history, are at the same time parts of the contemporary cultural furniture of those scholars who study their changing aspects as objects of research. The phenomenon of war, however, for the majority of contemporary historians and other observers in Europe and North America, has become a distant spectacle. So, what do we really know about war? And what do we want to know about war?

Since the Second World War, our experiences of war and our attitudes to it have lacked definition. While there have been dozens of prolonged armed conflicts around the globe, most Europeans have lived for more than fifty years without the experience of any real war. The elder generation still preserves the memory of war within our own countries, but most of us have knowledge of contemporary wars only from television that is, without any experience of imminent danger, fear, or death. The situation in the United States is even more ambivalent. It has been and is waging wars in distant parts of the world, sending out its own soldiers who have then created great tensions within their own country - not only as victims but also as survivors. Soldiers returned home from Vietnam, for example, with horrifying, unbelievable war experiences which it was almost impossible to integrate into the imagination of a society driven by economic progress and welfare.

In those decades the world also passed through a frightening period of cold war. Each nation had its own experiences but all were involved in a massive effort of ideological self-assertion. The leading powers of the world constructed a political identity in emphatic opposition to 'the great enemy': West against East, and vice versa. This oppositional political identity was intensified by totalizing ideologies of opposite economies and cultures.

After the breakdown of the communist world in 1989 , the surviving western world faced an identity problem. The old political and ideological oppositions had become secondary, and economic globalization seemed to have dissolved the political boundaries of identity. For a short time it could be questioned if the old model would continue to predominate - the model of precisely defined political identity constructed from

* I thank R. R. R. Smith for inviting me to give a concluding overview in a seminar series in Oxford on 'Art and War in the Ancient World', for recommending the paper to the editors of this journal, and for correcting and anglicizing my text. I also thank the Journal's anonymous readers for their precise comments. For helpful criticism and suggestions I am grateful to Bettina Bergmann, Barbara Borg, Jürgen
Franssen, William Harris and Emanuel Mayer. To Susanne Muth and Felix Pirson who read the text I owe many useful and stimulating contributions. The part of Fernande Hölscher with whom I discussed most of these issues is hard to define.

The illustrations are courtesy of the Archaeological Institute, University of Heidelberg. 
precisely defined enmity and hostility enhanced by aggressive ideology and propaganda. Formerly Western societies had their traditional enemies (in Germany 'the French', later 'the Russians'), but what was an enemy, what was political identity to become in the world of globalization? If political conflicts were to develop without precisely defined enemies and so become more complex, did they not also require more complex solutions?

To avoid such questions, the most far-reaching and complex conflicts in the world at the moment, particularly those between the Western and the Islamic worlds, are reduced and personalized by leading Western politicians to a fight against individual foes and clearly defined small groups of terrorist enemies. At the same time, these conflicts are conceived in terms of a simple ideological antithesis - between selfevidently positive Western values and foreign cultures full of dangerous and aggressive attitudes. This seems to be a deliberate withdrawal from the requirements of complex structural politics, and it results in an almost archaic concept of fight and battle. This simplistic and frightening stratagem is obviously well-suited to rouse collective emotions in favour of waging war in a society that is not so much concerned with the complex cultural and economic situations of other societies as with its own political and economic interests. The stratagem again divides the world conveniently into 'good' and 'bad'. The dangers of such anachronistic and simplistic thinking are evident. And it is in this context that it is urgent to find proper historical concepts for understanding war.

War in art is not war but art. It is a view, or a spectrum of views, of war seen through the medium of the visual arts - a mental and visual construct in a medium with its own specific possibilities and rules. This does not make the study of 'war in art' any less interesting or challenging. The images of war in all cultures are no mere visual fictions: they refer to hard, profound, and complex experiences in real life, to a world of killing and dying. A large part of the human and historical significance of wars thus lies not so much in their factual results (collective victory or defeat, individual triumph or death) as in the emotional, ethical, and ideological experiences and concepts connected with war and warfare. That is, a large part of the relevance of war in history lies in mentally constructed behaviour and perceptions. In this respect images are a highly revealing form of historical evidence: whether they confirm or complement written texts, they constitute an autonomous world of visual experience. ${ }^{1}$

Some basic theoretical premises for what follows can be briefly described. ${ }^{2}$ Firstly, all artistic images are of course mental constructs. As far as they represent the world of reality, they select specific subjects and motifs relevant for their purpose, focus on particular aspects of them, and enhance the expressive power of those chosen aspects. Images are thus reflections of cultural imagination. Secondly, reality too is a construct. The reality of war is determined and formed by particular technical conditions - arms and armour, logistical equipment, tactical and strategic concepts, patterns of behaviour and social ideals. Such conditions affect fundamentally the concrete and visual conduct of fighting. Reality in this sense is an image. Thirdly, the perception of reality is also a construct. A war or a battle can be perceived, for example, as a collective enterprise or as a series of individual achievements, as a glorious event or as a theatre of suffering and death. Perception in this sense creates images. And finally, such mental constructs are determined by cultural circumstances, specific to individual societies in different historical periods. Since such cultural constructs operate in different media - in the concrete world of real life, in psychological perception, and in visual representations they necessarily result in phenomena of different form and appearance. But in so far as they are produced by the same society, they will have some basic features in common. This underlying principle can be termed a society's specific cultural 'habitus'. ${ }^{3}$

\footnotetext{
${ }^{1}$ L. Hannestad, 'War and Greek art', 120-9, and N. Hannestad, 'Warfare in Roman imperial art', 146-54, in T. Bekker-Nielsen and L. Hannestad (eds), War as a Cultural and Social Force, Kongelige Danske Videnskabernes Selskab, Historisk-filosofiske Skrifter 22 (200I).
}

${ }^{2}$ For the following theoretical approach see: T. Hölscher, Formen der Kunst und Formen des Lebens (I995), I I-45.

${ }^{3}$ On social structures and habitus: P. Bourdieu, Outline of a Theory of Practice (1977). 
A brief look at two battle scenes from Greek and Roman art can demonstrate quickly the constructed character of ancient representations of war.

An Attic black-figure cup from the first half of the sixth century B.c. (Pl. I, I) represents a battle scene as a sequence of three duels, each between two warriors, equipped with shields and huge helmets and fighting with long lances. ${ }^{4}$ At first glance, it is easy to see that several features in this picture lack realism. Since battles in archaic Greece were fought - ideally and in some degree in reality - in close formations of soldiers (the phalanx), combat in duels does not correspond to the reality of archaic warfare. Moreover, the nude bodies and light tunics of the warriors were not the normal equipment of Greek hoplites. Scholars have interpreted these features as an idealization of aristocratic warfare. They are taken as anachronistic, designed to refer back to Homeric ideals, and to elevate contemporary warriors to the sphere of heroes. Although each of these interpretations may be questioned, there can be no doubt that the image is a visual construct.

Realistic battle-scenes on the other hand seem to be a domain of Roman art especially the reliefs on imperial arches, on the great battle sarcophagi, and on the columns of Trajan and Marcus Aurelius. A dramatic battle between massed forces is represented in a scene on Trajan's Column (P1. II, I-2). Roman units attack in closed formation from the left and put their enemies, the Dacians, to flight towards the right. Opponents are distinguished by their ethnic physiognomies and their equipment. ${ }^{5}$ This is a set-piece battle with two armies clearly ranged against each other in space, with clearly marked cultural distinctions between the two sides, and with many military and episodic details which give the scene the character of immediate realism.

The contrast between battle-scenes from archaic Greece and imperial Rome seems to conform perfectly to the received idea of Greek idealism and Roman realism, in art as in other sectors of culture. There are reasons however for re-considering this contrast. Firstly, we might consider the viewers of these works of art. All potential users of archaic drinking-cups were members of the leading class of their respective polis and as such potential members of their polis's army. They all had, or expected to have, real experience of war. They knew about what they were looking at. Conversely, among the audience of public monuments in imperial Rome, such as Trajan's Column, few would ever have witnessed real warfare.

The expectations of different viewers need not of course have determined the degree of realism in these representations of war. ${ }^{6}$ We might ask however whether and how far such circumstances affected the way in which war was conceived in images. We might expect that those who actually participated in war (for example, the cup users) wanted or claimed to recognize something that corresponded to their real experiences. This need not be a representation of 'objective reality' and might as easily be an ideological construction designed to give their achievements individual and collective value. But even such ideologically shaped images should probably refer recognizably to real aspects of war that the participants had themselves experienced. In the case of nonparticipants (for example, the viewers of Trajan's Column), the distance between them and the military action represented naturally encouraged more explicit ideological interpretations of war and military conquest. In this context, however, a concerted effort was often made also to visualize in detail achievements that had taken place far from the spectators' own experience. Such images worked to exemplify an ideology of victory by presenting factual-looking evidence.

We should leave aside therefore preconceived ideas about 'idealism' and 'realism' and be prepared for a great variety of perceptions of war and warfare. It was through

${ }^{4} A B V$ 52, ro; H. A. G. Brijder, Siana Cups I and Comast Cups (1983), pls 9b, 23a; Chr. Ellinghaus, Aristokratische Leitbilder - demokratische Leitbilder. Kampfdarstellungen auf athenischen Vasen in archaischer und frühklassischer Zeit (1997), 12-13.

${ }^{5}$ K. Lehmann-Hartleben, Die Trajanssäule (1923), Taf. 14, 23, 34; F. Coarelli, La colonna traiana (I 999), tav. $2 \mathrm{I}-4,42-5,8 \mathrm{I}-3$.

\footnotetext{
${ }^{6}$ Emmanuel Mayer reminds me of the reactions to the First World War in Germany: immediately after the war the surviving soldiers kept highly idealizing memories of their experiences, and more critical and 'realistic' accounts were produced only later - such as E. M. Remarque's Im Westen nichts Neues, first published in 1929 .
} 
such highly varied perceptions that military reality and ideological concepts were made to relate to each other, in specific and shifting ways.

Four basic aspects of war in ancient art may be singled out for investigation. Each brings out some general features of Greek and Roman culture.

(I) War and fighting as military activity. In the mirror of art, this concerns the psychological experience of war, that is, of threat, violence, and death.

(2) War as the construction of political dichotomies. War defines oppositions between one subject group and others, and between a collective self and a collective enemy. It is the most extreme form of realizing identity and otherness.

(3) War as legitimized killing. War entails a collectively defined and legitimized transfer from life to death. This aspect takes us into the sphere of cultural anthropology.

(4) War in public memory. Public monuments produced to memorialize war are concerned with its ideological exploitation as a foundation of political power.

These aspects of war can be considered as cultural phenomena in various contexts from a distanced, comparative point of view. This article thus draws material from the Greek as well as the Roman world not in order to present a magnificent panorama but to sharpen the eye to specific differences between these ancient societies and to bring out the otherness(es) of antiquity in comparison with contemporary experiences. To lay out such ideas briefly, instead of in a book, means inevitably a lack of nuance, of which I am here conscious.

\section{MILITARY REALITY AND PSYCHOLOGICAL EXPERIENCE}

\section{Modes of Combat}

Archaic battles were conceived as a fight between compact phalanxes. The army arrayed for battle and its manner of fighting embodied an ideal of civic coherence and generated a distinctive spirit of practical and ethical solidarity and homogeneity which had its social equivalent in the ideal of homoiotes, equality among the polis's citizens. In art, this ideal of the compact citizen phalanx is represented, for example, in one of the friezes of the famous Chigi jug (Pl. I, 2), where impressive and coherent files of soldiers repeat the same type of warrior. ${ }^{7}$

Whereas archaic art was thus fully capable of depicting such collective units, this was evidently not how battles were normally perceived, as the great majority of archaic vases that represent battles as a series of duels attests (P1. I, I). Single combats dominate even in large, developed compositions, such as that on an ointment pot in Paris ( $\mathrm{Pl}$. V, I). ${ }^{8}$ The traditional historian's question whether these representations are or are not faithful evidence of archaic warfare is misleading. The well-known answer that they present an idealizing stylization of warfare in terms of Homeric concepts of heroic valour does not address how such representations were compatible with the reality of contemporary wars. Since these depictions must be evidence of how fighting was actually conceived and also at some level how it was experienced, we should rather ask how these representations relate to military practice and how we should explain the fact that fighting in war was experienced in this form. ${ }^{9}$ 
Evidently the experience of collective fighting lost some of its importance at the moment the phalanxes clashed with each other and the soldiers began to fight. ${ }^{10}$ Precisely this moment is shown on the Macmillan oil-flask in the British Museum (Pl. $I, 3)$ on which coherent attacking phalanxes are shown on one side and single groups of fighting hoplites on the other. ${ }^{11}$ In order to understand such an image as a representation of real psychological experience, we need to remember that in archaic warfare there was almost no collective strategy in which the individual soldier was merely one element. The leader of the army in fact played a very restricted role: he had to line up the phalanx in good order and to give the signal for attack, not much more. Close formation had to be kept during the advance, but once joined the battle was primarily between single warriors with few neighbours and few adversaries. The isolation of the individual warrior was enhanced by the design of archaic helmets - especially that used most frequently the 'Corinthian' helmet with its small eye-slots which allowed no broad view around but concentrated its wearer's eyes exclusively on his immediate opponent. ${ }^{12}$ Nothing beyond this face-to-face encounter would be perceived. And this was surely a dominant experience of early Greek warfare - in spite of the conceptual coherence of the phalanx. According to Thucydides, 'those who are present (in a battle) do not know everything that happens, but each man knows barely what happens near himself' ${ }^{13}$

This archaic battle style became an all-embracing ideology of agonistic excellence enhanced by Homeric ideals of valour. Close fighting with lances was valued as the only real proof of arete, in contrast to the contemptible fighting of archers from a distance with bow and arrow. ${ }^{14}$ This conception of face-to-face fighting was thus at the same time a compelling ideal of manly excellence and a vital experience of reality. It is expressed in the innumerable compositions of duel and group fighting in Greek art. There may be in the experience and representation of warfare an inherent ambivalence between the individual and the collectivity, but in early Greek art this ambivalence is particularly sharply expressed. Both kinds of representation - collective battle formations and single duels - are neither correct nor incorrect versions of military reality. They are complementary views of the same reality, and in this sense they are legitimate representations of real experiences.

This phenomenon can be generalized. Face-to-face interaction corresponds to a basic structure of early Greek societies. ${ }^{15}$ In the community of the polis, the most important collective activities - the political decisions in the citizens' assembly, the rituals of religious festivities, the contests of athletic and musical agones - were occasions of intensive personal interaction and confrontation, face to face. Individual activities and experiences were not subjected to major, collective actions of higher relevance. In the same way, early Greek figurative art, independent of specific themes, is determined by a particular conception of space and action based on the single person and his immediate potential for action. There is no continuous space in which individual actions are subordinated to a comprehensive whole. All actions are represented as dealing with immediate partners or opponents, and so are limited in space to the reach of the persons' limbs, implements, and weapons. In the realms of social life and visual

${ }^{10}$ See T. Hölscher, Griechische Historienbilder des 5. und 4. Fahrhunderts v.Chr. (1973), 28-30; A. Stewart, Art, Desire, and the Body (1997), 89-93; van Wees, op. cit. (n. 7).

${ }_{11}$ C. Smith, 'A protocorinthian lekythos in the British Museum', $7 H S_{1}$ I (1890), I67-80, with pl. II. See Cartledge, op. cit. (n. 7), 689, on Homer's emphasis on single duels within the frame of mass battles: 'L'importanza apparentemente fondamentale dei duelli tra singoli eroi è un'illusione creata col ricorso dei poeti all'espediente quasi "cinematografico" della messa a fuoco o dello zoom sulla singolare tenzone dei protagonisti a fini drammatico-narrativi.' See recently O. Hellmann, Die Schlachtszenen der Ilias, Hermes Einzelschriften 83 (2000).

${ }^{12}$ See V. D. Hanson, The Western Way of War (i 989 ), esp. 19-26, 71-5, I35-59; idem, 'Hoplite technology in phalanx battle', in V. D. Hanson (ed.),
Hoplites. The Classical Greek Battle Experience (1991), 63-84; J. Lazenby, 'The killing zone', in ibid., $87-120$, esp. $93-102$.

${ }_{13}$ Thucydides 7.44.I (trans. C. F. Smith, Loeb Class. Library).

${ }^{14}$ On the ideal of individual fighting, face to face, see for example Homer, Iliad 2.604; Euripides, Rhesos 5 I0-II. Lance against bow: Homer, Iliad I I.384-90; Archilochos Fr. 3 Diehl = fr. 3 West; Strabo I I.I. I 2; Hölscher, op. cit. (n. 10), 42-3, r 54; Cartledge, op. cit. (n. 7), 699-700, on Thucydides 4.40 and 'ideologia oplitica'.

${ }^{15}$ See Chr. Meier, Politik und Anmut (2000); T. Hölscher, 'Images and political identity. The case of Athens', in D. Boedeker and K. Raaflaub (eds), Democracy, Empire and the Arts in Fifth Century Athens (1998), 353-85. 
representation, we may define early Greek culture in this way as a culture of immediate and autonomous action and interaction.

From the Hellenistic period the conception of relatively autonomous fighting is superseded in art by new structures of composition, which again correspond to specific concepts of military strategy. The first and best example is the Alexander mosaic from Pompeii, a reliable version of an early hellenistic painting, representing a victorious battle of Alexander the Great against the Persians (Pl. III, I) ${ }^{16}{ }^{\text {The opposing armies }}$ are clearly distinguished by their equipment as well as their configuration in space. Alexander charges from the left into the centre of the Persian army followed by his companion cavalry who are depicted in highly individualized actions. The Great King in his chariot turns to flight at the last moment, while some of his most devoted subjects throw themselves desperately in the aggressors' way. The soldiers around the Great King are seized with fear and despair, and others are brutally run over by his chariot and horses, while in the background a (probably) Greek detachment with long lances surrounds the Persian centre. Each individual action is made to relate to the action of the whole, far beyond the reach of any individual combatant. All the figures participate in and contribute to a collective event which is more than the sum of its single elements.

In a general way this composition corresponds clearly to the development of military strategy in the fourth century and later. This is best documented in the case of Alexander the Great. Alexander used the units of his army like chess-figures in a strategic plan in which all parts had different tasks and movements and were coordinated in a complex collective enterprise. The physical reality of killing and dying cannot have changed fundamentally, but as units and individual soldiers became tools within an overall strategic plan, so the experience of autonomous fighting and individual glory would have been correspondingly reduced. This does not imply of course that the picture is a realistic depiction of a specific battle. The crucial point is that the strategic plan and the artistic composition are guided by an analogous conception of the role of the individual person within a comprehensive whole.

This new conception of space seems again to be of wider importance. It corresponds to an experience of the world in which each individual performs his own actions and experiences his own destiny but one in which those individual actions and experiences were also conceived as part of a comprehensive network of interdependent elements. In a preliminary generalizing way, this phenomenon, which needs thorough investigation, may be conceived as characteristic of the Hellenistic world. The integration of autonomous cities and autonomous citizens into large territorial states ruled by distant kings and their subordination to large-scale changes and processes must have created a psychological situation in which the individual felt to a considerable degree dependent on major forces and on a kind of general destiny or Tyche that was more than personal fate. Hellenistic warfare may be seen in this perspective as a symptom of this general situation.

Similar compositions can be seen in Roman reliefs such as the great battle scenes on Trajan's Column. The Romans attack and the Dacians retreat in coherent group formations, and, behind the Roman front line, the emperor receives the cut-off heads of enemies killed (Pl. II, I-2). Single figures and military units are again conceived as factors in a collective endeavour which transcends the autonomy of individual actions.

In precisely the same period, however, a new conception of imperial warfare is represented in the Great Trajanic Frieze. The frieze belonged originally to an unknown monument of Trajan and was re-used in the Arch of Constantine. ${ }^{17}$ The general composition follows the principle of mass fighting in coherent units: the Romans attack from the left and overrun the helpless Dacian enemies on the right. But the emperor himself appears at the head of the attacking force. This is of course not the realistic motif it was on the Alexander mosaic. Roman emperors and their generals, unlike

${ }^{16}$ B. Andreae, Das Alexandermosaik aus Pompeji (1977). For the specific aspects of space and action see Hölscher, op. cit. (n. Io), I62-9; Hölscher, op. cit. (n. 2), 30-6.
17 M. L. Leander Touati, The Great Trajanic Frieze (1987), pls 1-4, 56; B. A. Andreae, Römische Kunst (1973), Abb. 42I-4. 
Hellenistic kings, never played the role of personal leaders of their troops in battle. As represented on the column, they commanded their armies from a distance. The emperor's position in the Great Trajanic Frieze is a symbolic one, and this kind of symbolic composition is predominant in other Roman battle scenes.

Similar compositions survive in a group of bronze horse pectorals that once belonged to imperial equestrian statues; these are decorated with appliqué figures which make up impressive battle compositions (Pl. III, 2). ${ }^{18}$ The victorious emperor himself appears on horseback in the upper centre of the composition in an elevated position. Below him to both sides Roman soldiers are defeating the enemy. This is hardly a coherent, continuous battle action. The central elevated position of the emperor contains a symbolic message. The emperor here does not even go into action but appears above the tumult with his right hand outstretched in a kind of victorious epiphany. Since these horse pectorals have been convincingly dated to the early imperial period, we must recognize that there were various and different modes of representation employed at the same time. The famous Ludovisi sarcophagus of the third century A.D. shows this kind of symbolic composition in its purest form. ${ }^{19}$ Such compositions do perhaps even greater violence to reality than the fragmented actions of archaic battle scenes. Later, below, we will try to define a theoretical frame for this kind of symbolism.

\section{The Warrior's Body}

Archaic battles were fought with full heavy hoplite armour: shield, helmet, breastplate, greaves, even arm-greaves, and lances and swords. No hoplites wore only a light linen shirt and even less did they appear with nude bodies, as they do in many vase paintings (P1. I, I) and reliefs. Hoplite armour was an important symbol of wealth, social rank, and full citizenship, but armaments did not encompass the full reality of warfare. A powerful body was also considered a decisive factor in fighting. ${ }^{20}$ The emphasis on physical strength and agility went together with the idea of fighting as proof of individual bravery, in which the individual warrior (as observed earlier) was not subordinate to a collective strategy. The powerful male body, trained by naked exercise in the palaestra, exposed in rites of passage from childhood to manhood, and celebrated in public athletic games, was a prerequisite of successful warriorship.

How much the trained naked male body was appreciated both as a real and as a symbolic factor in military fighting is evident from two famous episodes from fourthcentury Sparta. When Spartan troops under Agesilaos were confronted by a much larger Persian army and began to despair, Agesilaos publicly stripped some Persian captives of their clothes, exposing pale bodies that had never trained in a Greek palaestra. This upifting demonstration resulted in an overwhelming Spartan victory. ${ }^{21}$ Conversely, when some years later a Theban army had invaded Sparta itself, a certain Isidas ran out from his house, totally naked, his body rubbed with oil like an athlete, and put the enemy to flight. ${ }^{22}$ This was of course no normal custom, and of course Greek battle scenes with nude warriors do not refer to such episodes, but the well-trained body was a decisive reality of military fighting, even when covered with clothes and armour. This reality was described and made visible in works of art, regardless of whether it was

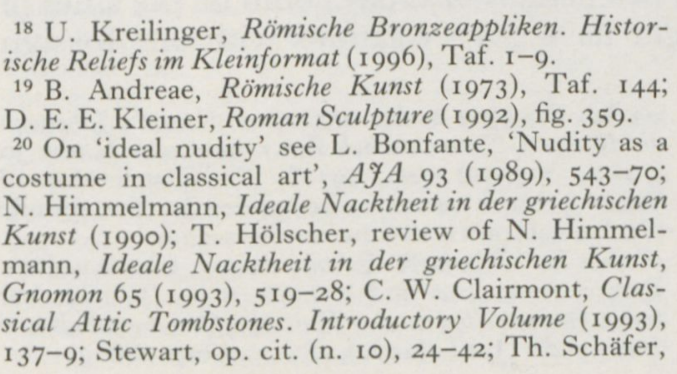

Andres Agathoi (1997), I2-14; T. Hölscher, Aus der Frühzeit der Griechen. Räume, Körper, Mythen, Lectio Teubneriana 7 (1998), 30-56; N. Himmelmann, 'Klassische Archäologie - kritische Anmerkungen zur Methode', $\mathcal{F} d I$ I I 5 (2000), 253-323, esp. 296-309. See also L. Foxhall and J. Salmon (eds), Thinking Men. Masculinity and its Self-representation in the Classical Tradition (1998).

${ }^{21}$ Xenophon, Hellenica 1.28. I apologize for repeating these stories which $I$ have quoted in various former essays on this topic.

${ }^{22}$ Plutarch, Agesilaos 34.6-8. 
visible in a battle. It is a reality not of instantaneous visibility but one that has to do with cultural functions and psychological perception.

The nude body of Greek warriors in art is therefore not a phenomenon of idealization: the body was a real factor in the conception of war. Since nudity frequently characterizes anonymous warriors without elevating them above other warriors wearing armour or clothes, it also does not signify heroization. And since it gives expression to a concept of definitely contemporary significance, it is not a Homeric anachronism either.

In the Hellenistic age, when athletic training lost its central significance as the social foundation of warfare, nude bodies of warriors became obsolete in Greek art. The Alexander mosaic has no nude soldiers (Pl. III, I), and it would be shortsighted to explain this as a straightforward result of hellenistic realism. Evidently the body as a conceptual factor in military action and virtue, as in other sectors of culture, had lost its centrality.

On Roman monuments, the valuation of the body and of physical action can even be reversed. The battle scenes on the column of Trajan are again revealing (Pl.II, I-2). Here, nudity and dramatic physical action are features of the ferocious semi-romanized German auxiliaries. The more civilized normal auxiliaries are equipped with flexible corselets suited to their varied deployment. The most valuable troops, the legionaries, are held in reserve in a motionless posture, covered by rigid breast-plates that conceal their physical qualities. ${ }^{23}$ The scale of values has been turned around: pure physical strength now has a low valuation, and high esteem is reserved for superior technical skill and static dignity.

We might be tempted in this context to speak again of Roman realism, but here too we have to be cautious. Some of the helmets of the legionaries are not of the well-known types used in the Roman army of the time but revive an obsolete Attic type. ${ }^{24}$ The high technical level of Roman equipment is thus ennobled by a reference to classical Greek traditions. This too was perhaps less realistic than the nude bodies of archaic warriors.

\section{ANTHROPOLOGICAL CONDITIONS}

War can be seen, according to the famous definition of Clausewitz, as the continuation of policy by other means. This is an abstract point of view. Images of war can be seen as artistic creations and as steps in the history of art. This is an aesthetic point of view. We need to remember however that war, and even war in art, has to do with very immediate experiences of enmity, danger, fear, and death.

\section{Enemies}

From its 'Dark Age' down to the sixth century B.C., early Greece developed without the threat of foreign enemies. ${ }^{25}$ The great political powers of Egypt and the Near East were in decline, and none of them aimed at expansion in the Aegean. There was, in these circumstances, no conception or image of a general enemy of the Greek world. Military conflicts arose mainly between individual Greek poleis, and political constellations could change from one moment to the next. The enemies of today could be the allies of tomorrow; the majority group in a polis might have good relations with one foreign

${ }^{23}$ German auxiliaries: Lehmann-Hartleben, op. cit. (n. 5), Taf. 14/XXIV centre, 3I/LXVI-VII centre, 33/LXX, 34/LXXII centre; Coarelli, op. cit. (n. 5), tav. 22, 73, 78, 82. Regular auxiliaries: LehmannHartleben, Taf. 3I/LXVI-VII centre, 34/LXXII right; Coarelli, tav. 22, 73, 82. Legionaries: LehmannHartleben, Taf. I4/XXIV left, 31/LXVI-VII left, 34/ LXXII left; Coarelli, tav. 21, 72, 82.

${ }^{24} \mathrm{G}$. Waurick, 'Untersuchungen zur historisie- renden Rüstung in der römischen Kunst', fahrbuch des Römisch-Germanischen Zentralmuseums Mainz 30 (1983), 265-301, esp. 293-6. The distribution of 'Attic' helmets seems to be guided by the specific ideological contents of the various scenes.

${ }_{25}$ See T. Hölscher, 'Feindwelten - Glückswelten. Perser, Amazonen und Kentauren', in T. Hölscher (ed.), Gegenwelten zu den Kulturen Griechenlands und Roms in der Antike (2000), 287-320, esp. 288-9. 
polis, the minority group with another, opposing polis; and one would meet one's enemies in war as peaceful competitors and co-worshippers of Zeus at the next festival at Olympia. ${ }^{26}$ The conflicts of the early colonists with the indigeneous populations at the 'borders of civilization' in the far West and North did little to change the ideology of hoplite fighting. Thus the early Greeks did for a long time without the concept of a foreign enemy of their way of life. ${ }^{27}$ They were more concerned with various and changing adversaries within their own world who had the same cultural standards. From the accepted equal standing of warring opponents developed the set of ethical rules, practices, and rituals of war which in their bloody conflicts were observed by the élites of the various poleis. ${ }^{28}$

This shared set of rules and rituals should explain a number of striking features in both the practice and representation of archaic war - why battles were normally fought in remarkably regularized forms; why representations of hoplite fighting so often show equivalent opponents without any distinction of victors and victims; why in scenes of killing we never meet motifs of crude de-humanization, as in Assyria and Egypt; why victors and victims are often, even in scenes of flagrant violence, connected in a strange common sphere of psychological solidarity, based on a shared consciousness of mortality; why in Greek literature victorious heroes often reflect on death as the ultimate destiny common to victors and vanquished; and why single combat and individual valour predominate so heavily over the annihilation of a collective enemy. ${ }^{29}$

All this is not an idealizing view of art but corresponds in principle to the military practice of the period down to (say) the end of the fifth century B.c. This was a military practice determined by multiple social interconnections between political opponents.

Greek wars in archaic times were certainly no ballet performances but conflicts of bloody and cruel violence. Murderous fury was even considered an essential quality of the great warrior. Achilles, the mythical prototype of this raging fury, was the greatest model of warrior arete. How such ideas were represented in art is however highly revealing. Scenes of violence and bloodshed are for a long time relatively rare in representations of contemporary hoplite fighting, whereas in mythological combat there are many well-known cases of tremendous cruelty. Much blood is shed, for example, in the struggles of the gods against the giants, of Herakles and his companions against the Amazons, of Theseus against the Minotaur, and in many others. ${ }^{30}$ Utterly savage cruelty is on display, for example, when Achilles hurls the young Trojan prince Troilos through the air or throws him against the Trojans; when Neoptolemos attacks the old king Priam with the body of the young prince Astyanax; or when the victorious Greeks massacre the women and children of captured Troy. ${ }^{31}$ In such images of fury, a wild and dangerous aspect of warfare, which was nevertheless considered an essential part of heroic conduct, was transferred to the realm of myth. From these mythological images, we can see more clearly that images of contemporary fighting were consciously focused

${ }^{26}$ For exceptions, that is, for long-term constellations of 'friends' and 'enemies', see K. J. Hölkeskamp, 'La guerra e la pace', in S. Settis (ed.), I Greci (r 1997), II 2,48 I -539 , esp. $486-7$.

27 Hostile opposition to the emerging order of the polis was conceived characteristically on a more symbolic level: first in the fantastic realm of wilderness, represented in the animal friezes with lions, sphinxes, and other beasts, then in the myths about assaulting Amazons, centaurs, and giants. On this, cf. Hölscher, op. cit. (n. 25). In archaic times most foreign mythological adversaries, except for the centaurs, are shown as purely Greek warriors: giants, Amazons, Trojans.

${ }_{28}$ J.-P. Vernant (ed.), Problèmes de la guerre en Grèce ancienne (1968); Hölkeskamp, op. cit. (n. 26), $494-501$.

${ }_{29}$ Rare exceptions: e.g. A. Rumpf, Chalkidische Vasen (1927), pl. 88; K. Schefold, Meisterwerke griechischer Kunst (1960), 141, no. I29. Opposition of oriental and Greek concepts: P. Ducrey, 'Victoire et défaite. Réflexions sur la représentation des vaincus dans l'art grec', in $\mathrm{Cl}$. Bérard, Chr. Bron and A. Pomari (eds), Images et société en Grèce ancienne (1987). Common 'sphere of solidarity': e.g. the Villa Albani relief, R. Lullies and M. Hirmer, Griechische Plastik (1979), Taf. 172; J. Boardman, Greek Sculpture. The Classical Period (1985), fig. I 53.

${ }^{30}$ Gods against giants: e.g. LIMC IV 2 ( 1988 ), Gigantes nos 126, 170 . Herakles against Amazons: LIMC I 2 (198I), Amazones no. 7, cf. 41. Theseus against the Minotaur: LIMC VI 2 (1992), Minotauros $\operatorname{nos} 8$, 10, 1 8-20. Note also Ajax and Glaukos: Rumpf, op. cit. (n. 29), Taf. I2. Ajax and Hektor: K. Friis Johansen, The Iliad in Early Greek Art (1967), 67-8, fig. I 3 .

${ }_{31}$ Achilles and Troilos: LIMC I (I98I), Achilleus nos 35-77. Neoptolemos, Astyanax and Priamos: LIMC II (1984), Astyanax I nos 7-29. LIMC VII (1994), Priamos nos I I6, I I 8. Generally, see Ducrey, op. cit. (n. 29). 
on other values - that is, on the values and norms that resulted from the manifold political and social interconnections between the élites of the poleis of archaic Greece.

A new and strikingly negative image of barbarian enemies emerged in the Persian wars. ${ }^{32}$ Greek identity was now defined in extreme opposition to the cultural otherness of the eastern enemy. The new idea of a foreign enemy changed a whole system of values. On a drinking-cup in Paris (Pl. IV, $\mathrm{r})$, the defeat of a Persian warrior is depicted more drastically than is ever encountered in fighting scenes of archaic art. ${ }^{33}$ The Persians are not considered to be adversaries of equal value: they are absolute enemies who have to be crushed with violence. On another cup, lost today but preserved in a good drawing, Persians are represented sitting on the ground making idle gestures of defence. Their attitudes are the complete opposite of the ideal behaviour of Greek hoplites - an expression of moral helplessness unprecedented in earlier times. ${ }^{34} \mathrm{On}$ a higher conceptual level, a wine jug in Boston evokes a whole range of ideological oppositions: ${ }^{35}$ Greek agonistic nudity against the effeminate nature of the Persians; Greek simplicity against the luxury of oriental clothing; Greek lance fighting, face-to-face, against the oriental cowardice represented by the Persian's bow. There were of course other conceptions of the oriental enemy in play at the same time. Aischylos' Persians, for example, conveys a much more complex, in part noble image of the eastern enemy. We might imagine that the same Athenian citizens who had appreciated the performance of this play in the theatre during the day were delighted in the evening by the negative depictions on vases used at the symposion. In these vase images, the enemy became an ideological construction of otherness which was based on a new conception of collective identity: it embodied all that was strange and opposed to the collective self.

The constructed character of such images is strikingly evident in the radical change that the concept of enmity underwent in the Hellenistic age. During the fourth century a luxurious life-style on the eastern model had become widespread in Greece, so that the counter-image of luxurious, effeminate orientals lost its cultural significance. And after Alexander the Great had incorporated the Persian kingdom into his own multicultural empire, the counter-image finally lost even its political foundation. A new image of a foreign enemy was soon found and moulded in precise opposition to the refinement of contemporary hellenistic society. The new image was that of the uncivilized, ferocious Gaul, and its best visualization was in the famous victory monuments of Pergamon $\left(\mathrm{Pl}\right.$. IV , 2). ${ }^{36}$ The direct opposition between self and enemy is well demonstrated by this change of ideals and corresponding counter-images.

The Roman Empire's claim to world empire, which began with Augustus, produced a wholly different conception of archetypal enemies. Rome was no longer conceived as one pole in a bipartite world, as the pole of culture, right, and piety against the opposing pole of barbarism. Instead Rome was seen as the centre of the world between two extreme poles. These poles were supposed to delimit the whole universe, and they had therefore to stand themselves in opposition to each other. The result was a configuration of northern and western barbarians on the one hand and orientals on the other. The Gauls and Germans were stereotyped as rough and without civilization, though bold and trustworthy and therefore useful for minor military services. The orientals on the other hand were effeminized by luxury and full of deceit, though representatives of old civilizations and therefore appreciated for their cultural attributes. The Roman Empire was erected on these two oppositional foundations, impressively visualized in the Grand Camée de France where the emperor Tiberius and his dynasty appear above a mass of

${ }^{32}$ A. Bovon, 'La représentation des guerres perses', BCH 87 (1963), 579-602; W. Raeck, Zum Barbarenbild in der Kunst Athens im 6. und 5. Fahrhundert v.Chr (198I), ro I-63; Hölscher, op. cit. (n. 25), 30I-4.

${ }^{33} A R V^{2} 433,62$; D. Buitron-Oliver, Douris (1995), no. ro8, pl. 67; Hölscher, op. cit. (n. 25).

${ }^{34} A R V^{2}$ 417, 4; Bovon, op. cit. (n. 32), 582, fig. 7;

Hölscher, op. cit. (n. 25), 30I-2, Abb. 4.
${ }^{35} A R V^{2}$ 631, 38; Hölscher, op. cit. (n. 25), 303-4, Abb. 5 .

${ }^{36}$ E. Künzl, Die Kelten des Epigonos von Pergamon (1971); H.-J. Schalles, Untersuchungen zur Kulturpolitik der pergamenischen Herrscher im 3. Fahrhundert v.Chr. (1985); R. R. R. Smith, Hellenistic Sculpture (1995), 99-102; E. Polito, I Galati vinti (1999); Hölscher, op. cit. (n. 25), 304-5. 
combined northern and eastern vanquished enemies. ${ }^{37}$ The Column of Trajan carries an analogous and more elaborate representation of this imperial vision. ${ }^{38}$ Trajan's war is fought against a single enemy, the Dacians with their Sarmatian allies, while on the Roman side, beside the regular legionary and auxiliary troops, there appears a calculated selection of foreign peoples: club-warriors from Germania, archers from Palmyra, horsemen from Mauretania, and stone-slingers from the Balearic Islands - that is, allies from north, east, south, and west. All the world fights on Trajan's side against an isolated hostile foe. In such monuments, which are characteristic of Roman political art, we meet a complex representation of absolute superiority that makes Roman world empire visible in symbolic language.

\section{Killing and Subduing}

Enemies require killing. Killing is of course an action deeply rooted in anthropological conditions. It is the extinction of life, the intentional annihilation of being, and war is collective killing in specific, culturally determined forms. ${ }^{39}$ As every society has its specific forms of life, so it also has its own specific forms for the extinction of life especially the enemy's life, in war. Cultural concepts of killing and death in war therefore always depend on and reveal a society's concepts and ideals of life. Killing and life have to be considered in connection with each other. The following observations hardly exhaust this topic and are merely designed to show the conceptual force of such oppositions.

In archaic art victorious warriors are often represented in a single common scheme: striding forward and thrusting their lance against the enemy with their raised arm (Pl. $\mathrm{V}, \mathrm{I})$. This is a visual demonstration of physical energy and psychological determination. Their uniformity is surely not due to a lack of ideas on the part of the artists. It is a sign of conformity to fixed norms of warlike bravery and manly excellence. The same bravery and excellence, arete, is represented in a state of potentiality in kouroi, the statues of young members of the upper classes, with slightly advanced left foot and forceful arms. ${ }^{40}$ The fighting warriors in battle-scenes are kouroi set into motion. Just as the warriors in action, the kouroi are representatives of exemplary arete, and so they too are shown in normative uniformity.

Vanquished opponents on the other hand are depicted in the most varied postures fleeing, kneeling, crouching, and lying stretched-out on the ground. The weapons of victorious warriors often do not even hurt their opponents: defeat is represented by posture. In archaic art, the ideal life is shown as the uniform fulfilling of fixed norms of the community, while death is the multiform deviation from those norms.

In red-figure vase-painting of the classical period, the victors display their superiority in much greater variety and mobility. On drinking-cups with scenes of battle against Persian adversaries, Greek hoplites are depicted attacking their opponents in all kinds of postures. ${ }^{41}$ On a slightly earlier cup, a young warrior kills his elder Greek opponent with his sword in an extremely complicated posture $(\mathrm{Pl} . \mathrm{V}, 2){ }^{42}$ Such scenes evoke a sense of forceful agility. Vanquished enemies on the other hand - Greeks and

${ }^{37}$ Grand Camée de France: Andreae, op. cit. (n. 19), Taf. 57; J. B. Giard, Le Grand Camée de France (1993). Oriental enemies: R. M. Schneider, Bunte Barbaren (1986); idem, 'Die Faszination des Feindes. Bilder der Parther und des Orients in Rom', in J. Wiesenhöfer (ed.), Das Partherreich und seine Zeugnisse, Historia Einzelschriften, vol. I 22 (1998), 95-146. On northern barbarians, a dissertation is in progress by Chr. Heitz. General attitude of Rome towards their enemies: S. P. Mattern, Rome and the Enemy (1 999); I. M. Ferris, Enemies of Rome: Barbarians Through Roman Eyes (2000).
${ }^{38}$ T. Hölscher, 'Alle Welt für Traian', in Imago Antiquitatis. Mélanges offerts à R. Turcan (1999), $28 \mathrm{I}-9$.

${ }^{39}$ A study of violence in archaic and classical Greek art by $\mathrm{S}$. Muth is in preparation.

${ }_{40}$ J. Boardman, Greek Sculpture.The Archaic Period (1978), 22-4, and passim; W. Martini, Die archaische Plastik der Griechen (1990), 69-77; C. Rolley, La sculpture grecque I (1994), 165-75.

${ }^{41}$ supra, nn. 33-4.

${ }_{42} A R V^{2}$ I 18 , I3; J. Boardman, Athenian Red Figure Vases. The Archaic Period (1975), fig. I 14. 
barbarians alike - are deprived of their force and mobility. ${ }^{43}$ Lances and swords realistically wound and penetrate their bodies, and they are seized by drastic weakness and despair. This is a deficiency not only of normative behaviour but also of active mobility. This phenomenon can again be generalized. The great new theme of fifthcentury sculpture was potential mobility and agility, displayed in the new artistic system of contraposto. ${ }^{44}$ Life in classical art is mobility, and death is the annihilation of that mobility.

In Hellenistic times there was a further change of attitude to both victory and defeat. Victorious kings such as Alexander the Great are represented in highly unclassical attitudes of almost supernatural and explosive individual energy. ${ }^{45}$ Their barbarian adversaries can be characterized by a near-equivalent ferocity, but they turn it against themselves, annihilating this force by suicide (Pl. IV, 2). ${ }^{46}$ When this annihilation has been accomplished, as in another Pergamene victory monument, the result is an absolute extinction of physical vitality (Pl. VI, I $).{ }^{47}$ Life in Hellenistic art is energy, and death means the total destruction of this vital energy.

In Roman art the overwhelming superiority and power of the emperor is demonstrated not so much by physical vigour as by representative attributes and gestures - as for example in the statues of Augustus from Prima Porta and from the Via Labicana. ${ }^{48}$ Imperial qualities, such as auctoritas and dignitas, virtus and pietas, are demonstrated by significant equipment (the elaborate cuirass or the toga capite velato) and recognized gestures (the raised right hand or gestures of sacrifice). Such statues represent the claim and the posture of Roman world empire.

In this context defeated enemies are deprived of precisely those qualities of dignity and status which define Roman superiority. The Roman claim of worldwide rule goes closely with images of enemies in utter humiliation. ${ }^{49} \mathrm{On}$ the Gemma Augustea in Vienna, Augustus is surrounded in the upper zone by personifications of universal dominion, while in the lower zone - clearly a zone of symbolic inferiority - Roman soldiers drag a pair of vanquished enemies towards a trophy $\left(\mathrm{Pl}\right.$. VI, 2).$^{50}$ A peak of brutality and de-humanization is reached in the well-known scene on the Column of Marcus Aurelius where the brutality of punishment and slaughter is enhanced by the symbolic position of the Romans above their victims and by the expressive physiognomies of the defeated, distorted by pain and despair. ${ }^{51}$ In other compositions of more allegorical character, subjugated barbarians appear kneeling in servile attitudes - for example, supporting the symbols of imperial power and crouching at the foot of trophies $\left(\mathrm{Pl}\right.$. VI, 3) ${ }^{52}$ Life and power in Roman art is dignity and status, while defeat and death mean the systematic destruction of such dignity and status.

\section{IDEOLOGY AND PUBLIC MEMORY}

Wars are waged by political communities for political aims, and, throughout world history, it has been common practice for political entities, entire states as well as

\footnotetext{
${ }^{43}$ On the general increase of violence in warfare during the fifth century в.C., see Hölkeskamp, op. cit. (n. 26), 493.

${ }_{44}$ A. H. Borbein (ed.), Das alte Griechenland (1995), 260-2; B. Fehr, Bewegungsweisen und Verhaltensideale (1979), 25-30.

45 A. Stewart, Faces of Power (1993), 163-71, 427-8.

46 supra n. 36

${ }^{47}$ Smith, op. cit. (n. 36 ), 102-4, fig. 132

48 Andreae, op. cit. (n. I9), Taf. 34; P. Zanker, The Power of Images in the Age of Augustus (1990), figs 104 and I48a; D. Boschung, Die Bildnisse des Augustus, Das römische Herrscherbild I 2 (1993), pls 2 I3, 214; Kleiner, op. cit. (n. 19), 4I, 42.

49 P. Zanker, 'Die Barbaren, der Kaiser und die Arena', in R. P. Sieferle and H. Breuninger (eds),
}

Kulturen der Gewalt (1998), 53-86. Generally: Ferris, op. cit. (n. 37). Non vidi: T. Viljamaa, A. Timonen and C. Krutze, Crudelitas. The Politics of Cruelty in the Ancient and Medieval World (1 992).

${ }^{50}$ H. Kähler, Alberti Rubeni dissertatio de gemma Augustea (1968); Andreae, op. cit. (n. 19), Abb. 316; Zanker, op. cit. (n. 48), fig. I82; Kleiner, op. cit. (n. I9), fig. 47.

51 C. Caprino et al., La colonna di Marco Aurelio (1955), tav. XLIII, 85; F. Pirson, 'Style and message on the Column of Marcus Aurelius', Papers of the British School at Rome 64 (1996), I 39-79.

52 Schneider, op. cit. (n. 37, 1986), 18-97; Andreae, op. cit. (n. 19), Abb. 237; Zanker, op. cit. (n. 48), fig. 55; Kleiner, op. cit. (n. 19), fig. 64 . 


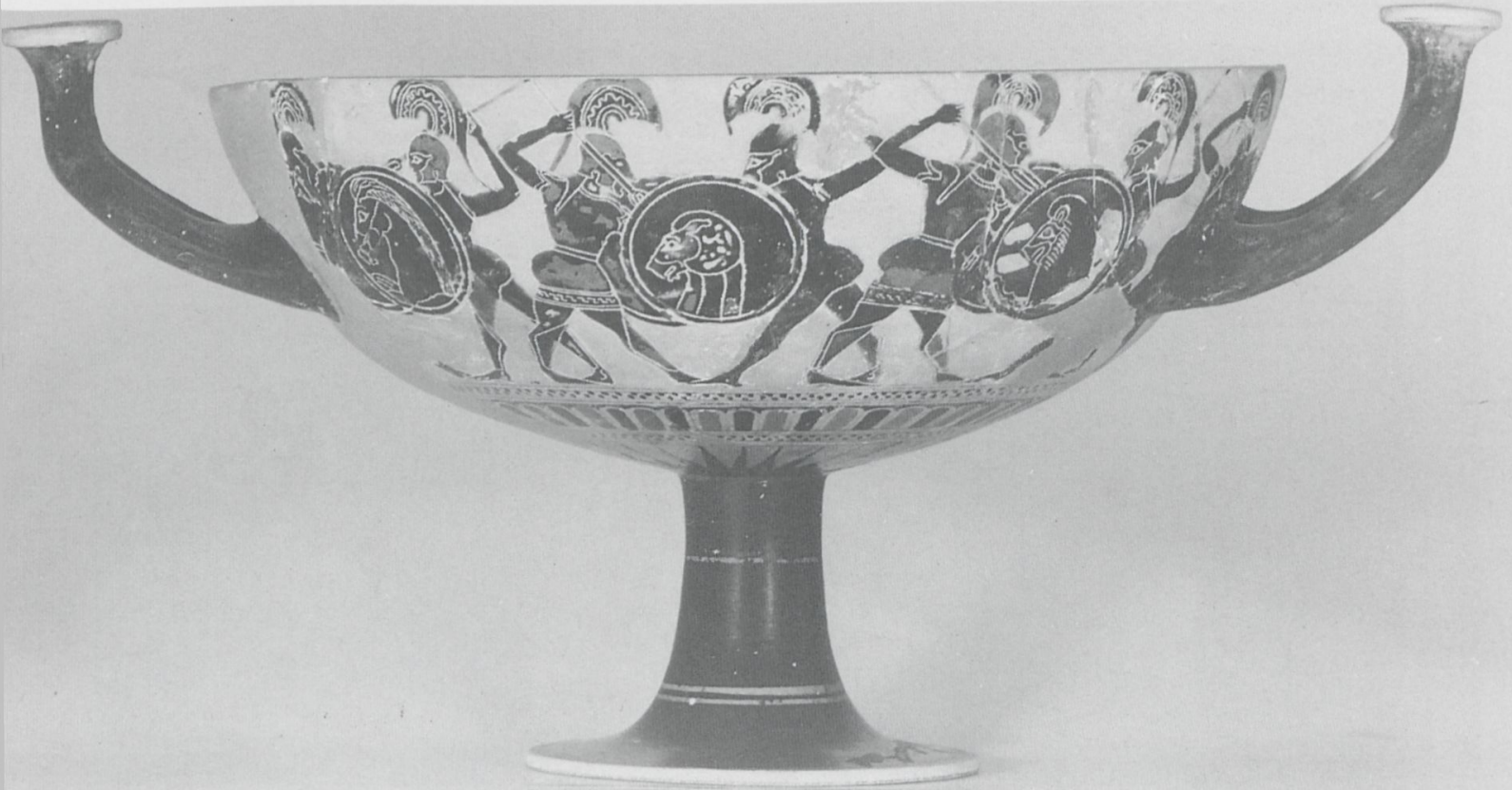

I. DRINKING-CUP FROM ATHENS. FIGHTING WARRIORS IN SINGLE DUELS. WÜRZBURG, MARTIN VON WAGNER MUSEUM. $c$. 560 B.C.

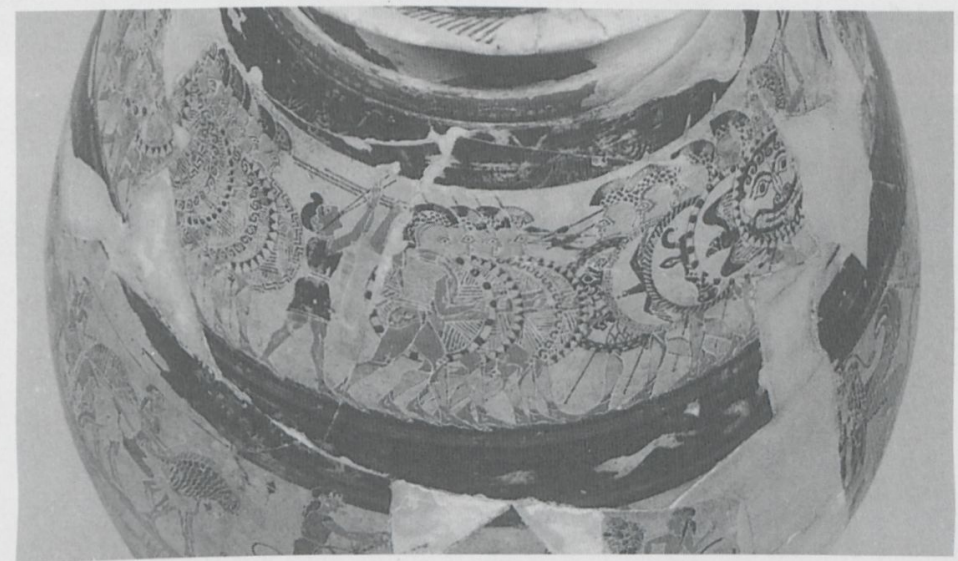

2. WINE JUG FROM CORINTH, 'CHIGI OLPE'. BATTLE OF TWO ARMIES IN 'PHALANX' FORMATION. ROME, MUSEO NAZIONALE DI VILLA GIULIA. c. 630 B.C.

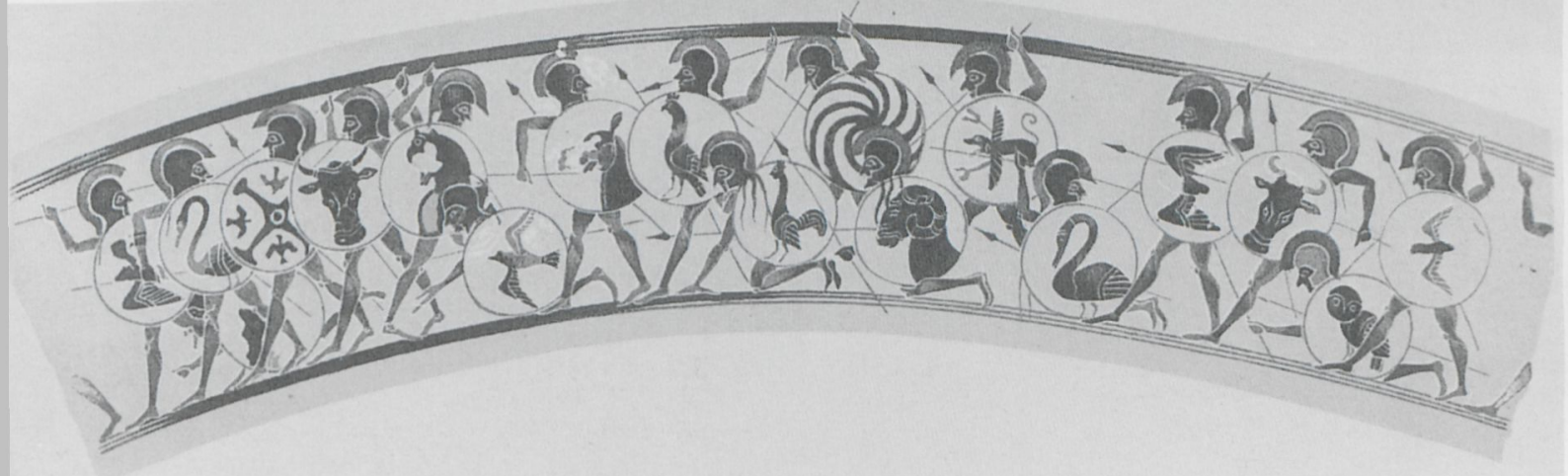

3. OINTMENT FLASK FROM CORINTH, 'MACMILLAN ARYBALLOS'. BATTLE IN 'PHALANX' FORMATION AND IN SINGLE COMBAT. LONDON, BRITISH MUSEUM. $c$. 630 B.C. 

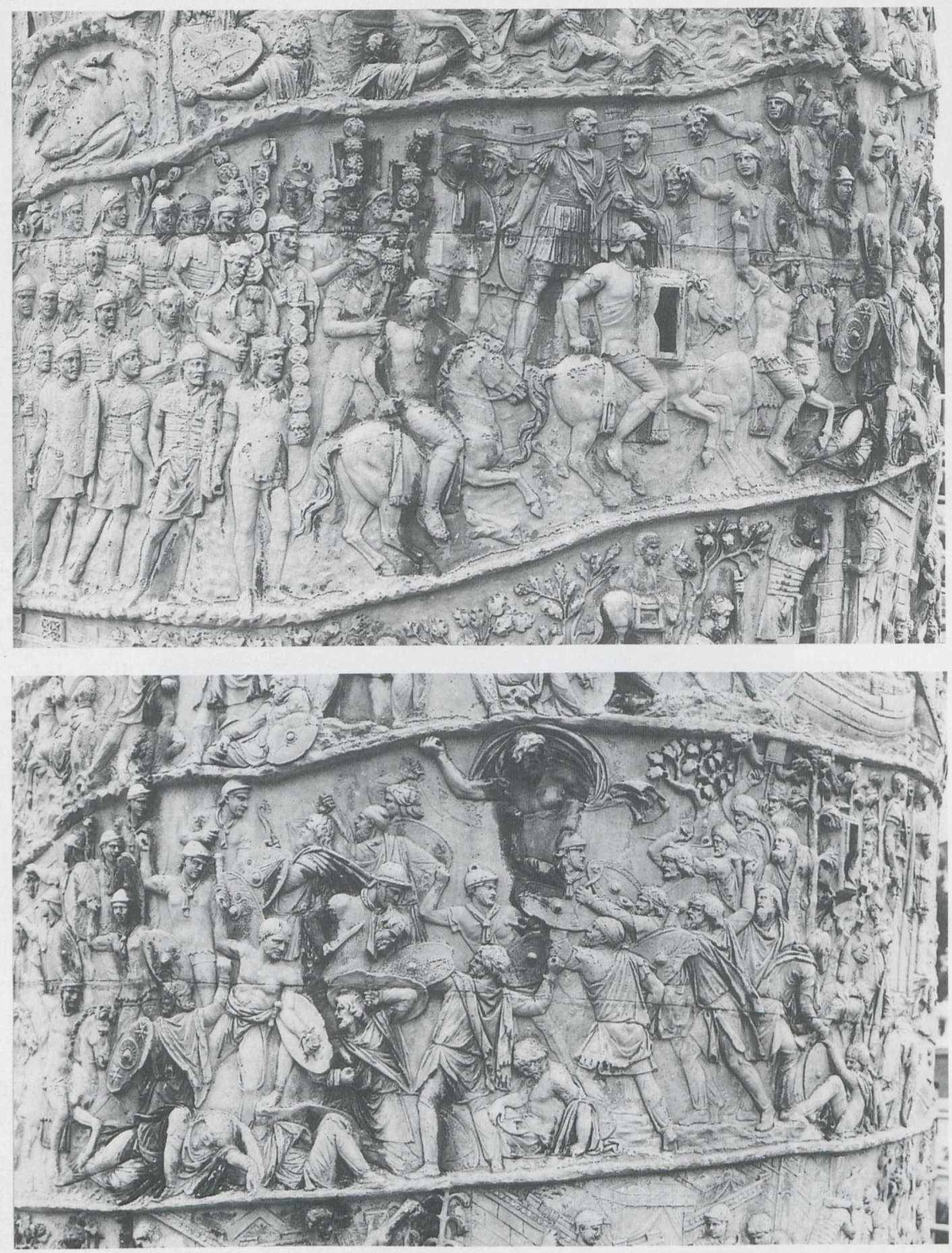

I-2. TRAJAN'S COLUMN. BATTLE BETWEEN ROMANS AND DACIANS. ROME. A.D. IO6-II6. 


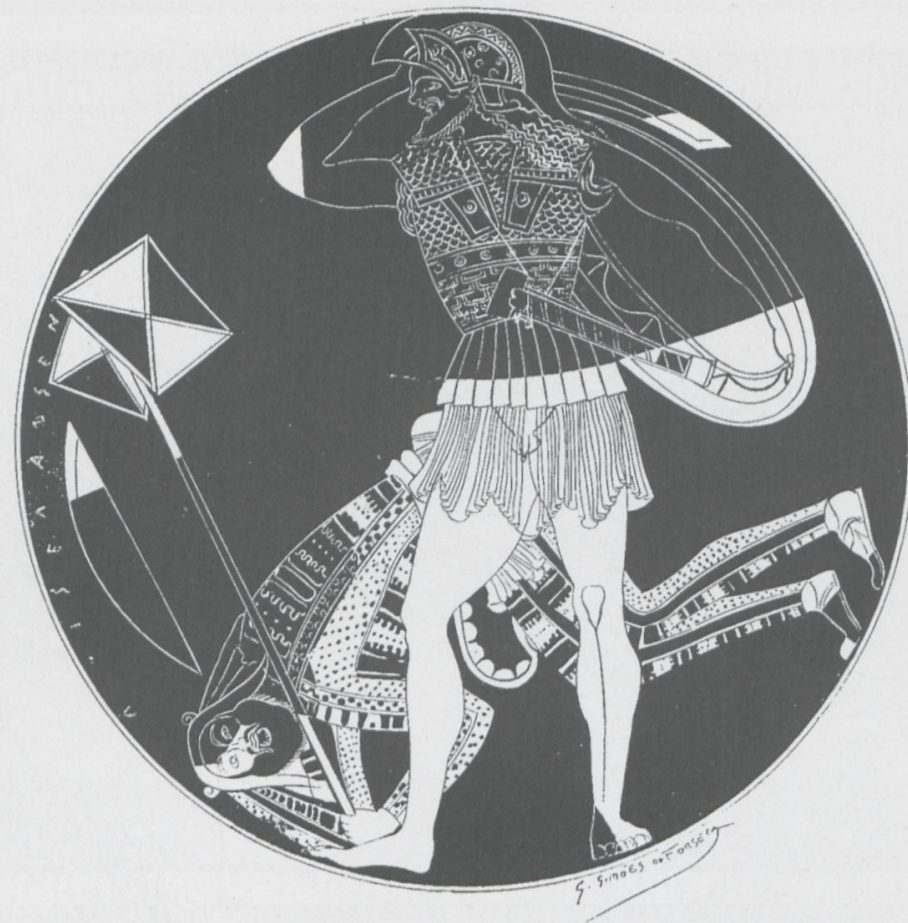

I. DRINKING-CUP FROM ATHENS. FIGHT OF GREEK AGAINST PERSIAN WARRIOR. PARIS, MUSÉE DU LOUVRE, $c$. $490-480$ B.C.

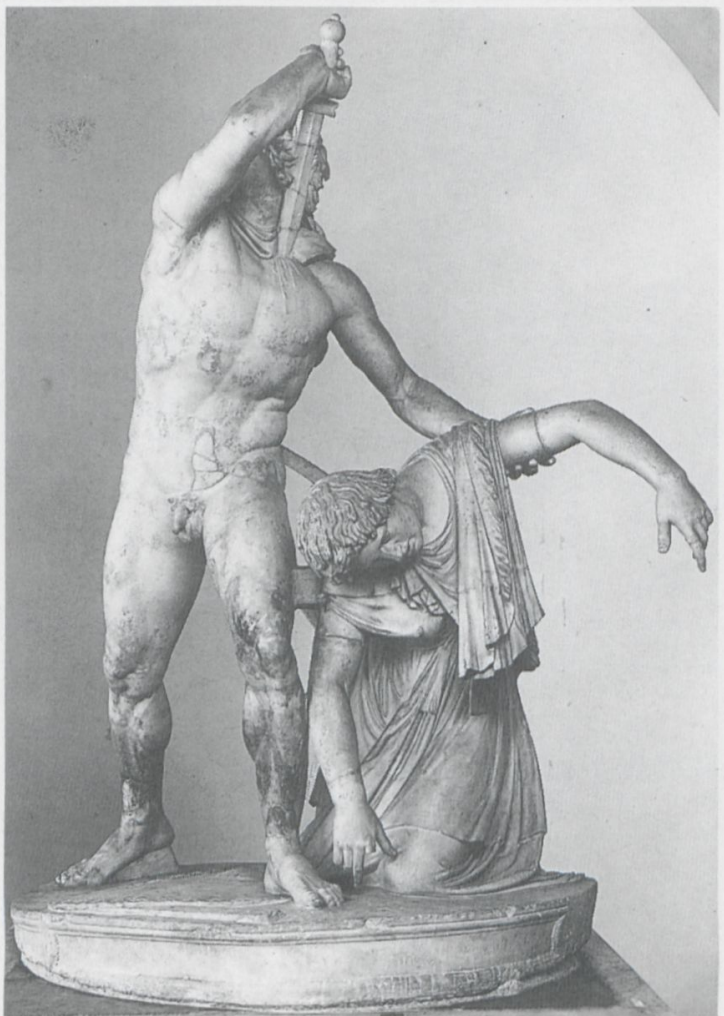

2. MARBLE GROUP, 'LUDOVISI GAUL'. GAULISH ChIEFTAIN, HAVING KILLED HIS WIFE, COMMITTING SUICIDE. ROME, MUSEO NAZIONALE DI PALAZZO ALTEMPS. ROMAN COPY AFTER GREEK ORIGINAL, PART OF THE 'GREAT ATTALID VICTORY MONUMENT'. c. 220 B.C. 


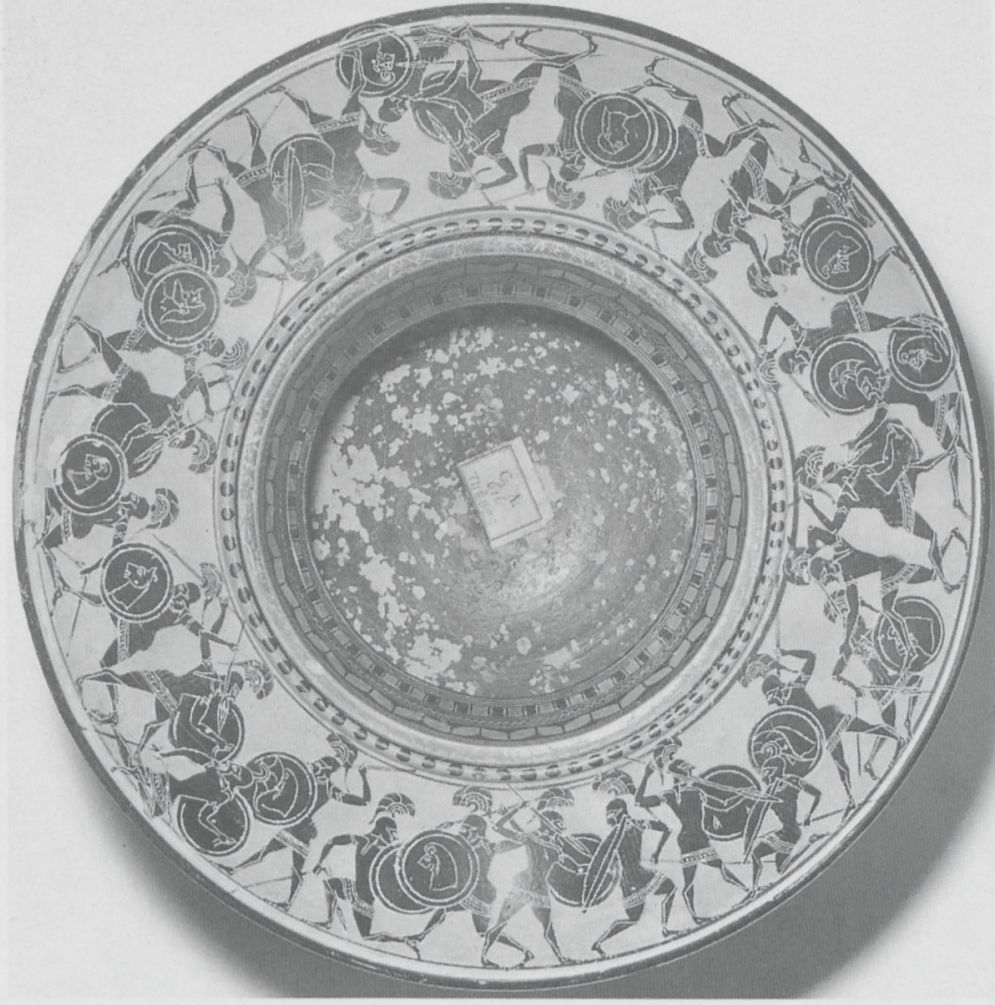

I. OINTMENT RECEPTACLE FROM ATHENS. FIGHTING WARRIORS IN SINGLE COMBAT GROUPS. PARIS, MUSÉE DU LOUVRE. c. 560 B.C.

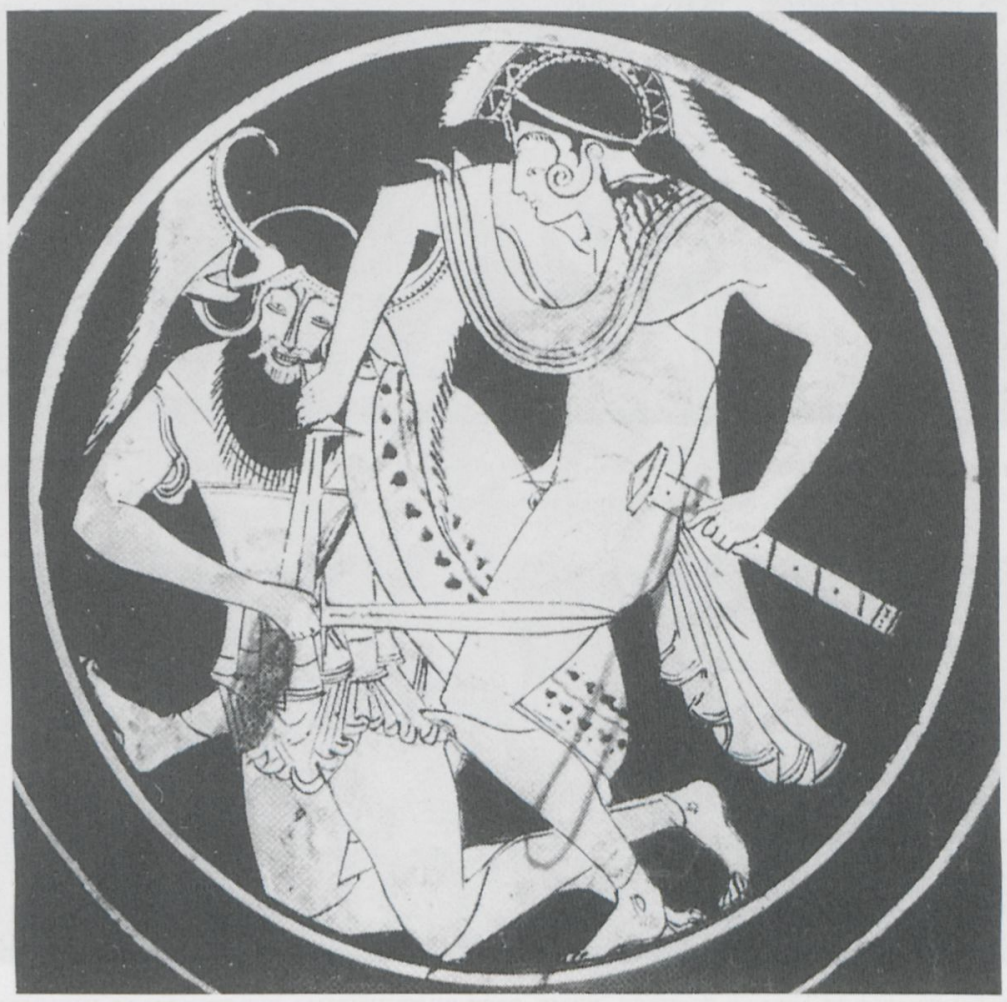

2. DRINKING-CUP FROM ATHENS. FIGHT BETWEEN TWO WARRIORS. LONDON, BRITISH MUSEUM. $c$. 50O B.C. 


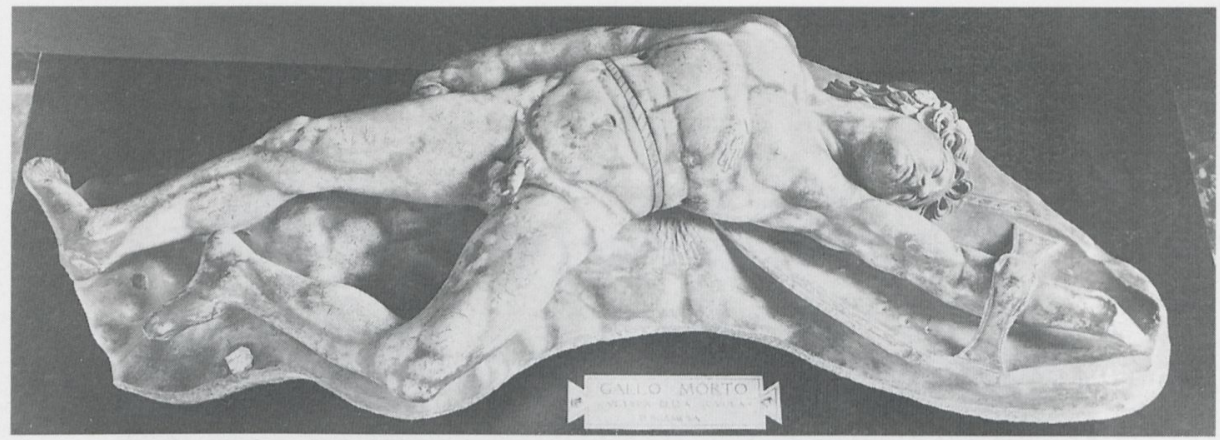

I. MARBLE STATUE. DEAD GAULISH WARRIOR. VENICE, MUSEO ARCHEOLOGICO. ROMAN COPY AFTER GREEK ORIGINAL, PART OF THE 'SMALL ATTALID MONUMENT', $c$. I60 B.C.

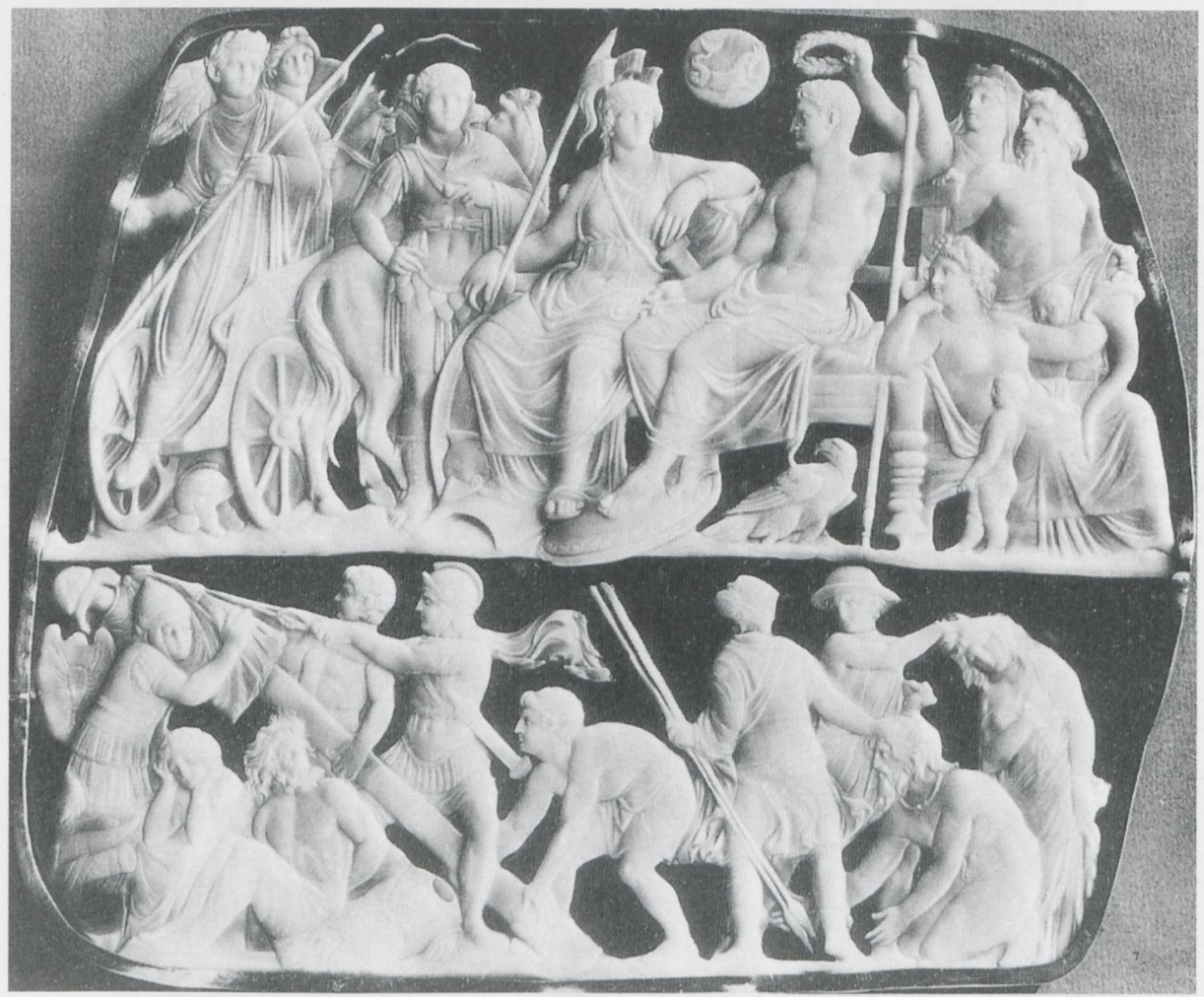

2. IMPERIAL RELIEF CAMEO, 'GEMMA AUGUSTEA'. ALLEGORY OF AUGUSTUS AND HIS WORLD DOMINION. VIENNA, KUNSTHISTORISCHEN MUSEUM. A.D. IO-I 4 .

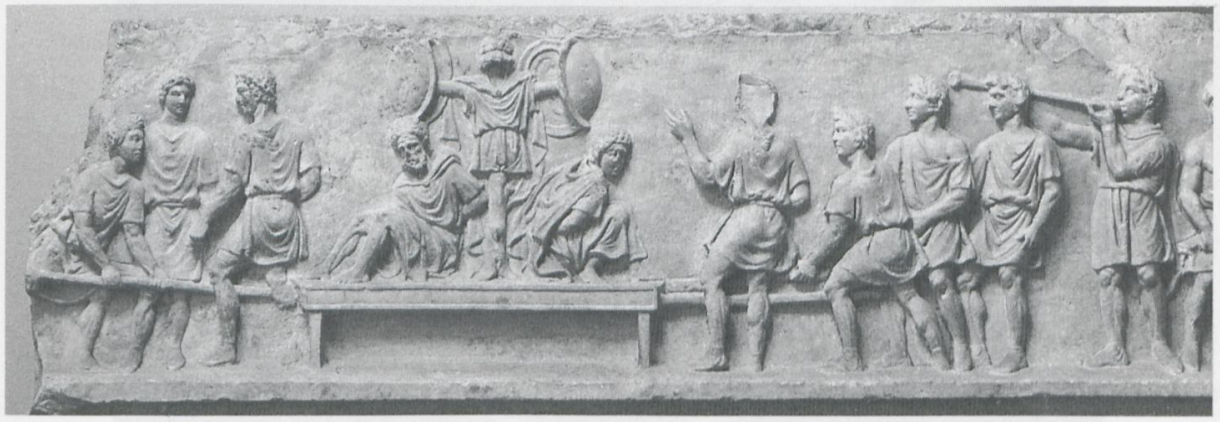

3. RELIEF FRIEZE FROM TEMPLE OF APOLLO IN CIRCO, ROME. PART OF TRIUMPHAL PROCESSION OF AUGUSTUS, WITH TROPHY AND CAPTIVES ON A BIER. ROME, MUSEO MONTEMARTINI. $c$. 20 B.C. 
individual rulers and statesmen, to base their political power or ambitions on military victories. Reaching for power through war has an external and an internal aspect.

Wars result in a new, more or less durable relation of power between the victors and the outside defeated community and in recognition of the victors' strength by other political communities. New ideas about the victors' superiority and dominion, which transcend their own realm, may develop from this recognition. Inside the victors' community on the other hand military victories strengthen the prestige, position, and power of those who claim to be the authors of the victories. This internal benefit has often - more often than external conflict - been the primary motivation of political leaders for beginning a war.

In larger states the difficulty of converting military victory into political power is correspondingly greater. ${ }^{53}$ Military victories are normally events of brief duration, whereas effective political power is a continuum. That is, victories are achieved by a small minority of the population, at a place usually far from the political centre, and at a specific moment, while political power is intended to embrace the whole political community, to extend over the whole realm of the state, and to be lasting in time. Military success has then to be converted into power that is something more than an event limited in space and time. This conversion aims to involve the whole population in victory.

Diffusion of military success to the community was achieved in antiquity primarily by three different means: rituals, monuments, and ideological concepts. Rituals included triumphal processions, sacrifices to the gods of victory, organized celebrations, and ceremonial departures and arrivals to and from military campaigns. Such rituals are especially effective in promoting an emotional participation of broad groups of the population. Monuments were commemorative works of art and architecture that celebrated military achievements. Such monuments could be erected in a variety of locations - for example, on the battlefield, at the border of the state's territory, and above all in its political centre. It was in a state's capital that the most influential political groups could be addressed both immediately after the victory and in the future. Ideology in this context refers to the broad range of means for spreading ideas of victory and dominion. Ideological claims could be transmitted by the spoken word, by literature, by various kinds of images, from public monuments to official coinage, and by symbolic actions that range from rituals to spontaneous demonstrations. These were perhaps the most efficient means of 'converting' or spreading the effect of military victory.

A crucial question concerning war and power is their relationship to religion. In both the Greek and Roman worlds those who waged wars respected the will of the gods, hoped for their help, and performed appropriate religious rituals. ${ }^{54}$ Nevertheless, the religious dimension was not as strong as in other states of the eastern Mediterranean world. There were no holy wars waged by order of a supreme city or state god. The ideology of war was thus determined less by religious ideas than by social, ethical, and political considerations. The political power of Greek statesmen and rulers within their own state, again in contrast to the ancient Near East, had no strong foundation in religion. This changed to some degree under the Roman Empire when religious means played a significant role in the conversion of prestige in war into political power.

While this is not the place for dealing fully with these issues, the following remarks try to describe the impact of some of these factors on art and visual representation.

\section{Rituals}

Rituals performed in larger or smaller groups are an efficient means of providing warfare with symbolic or ideal significance. They serve to strengthen solidarity,

${ }^{53} \mathrm{I}$ address this question more fully in a forthcoming
article in a volume on war in Roman art, edited by article in a volume on war
S. Dillon and K. Welsh.
${ }^{54} \mathrm{~W}$. K. Pritchett, The Greek State at War, vol. III: Religion (1979); J. Rüpke, Domi militiae. Die religiöse Konstruktion des Krieges in Rom (1990). 
psychological effort, and dedication to normative values. Due to their different social and political circumstances, war rituals in Greece and in Rome were of a considerably different character. Only some of them are depicted in art, and this selection may demonstrate which rituals were considered particularly significant in their respective cultural contexts.

In archaic and classical Greece, war rituals do not play any significant role in state monuments. Such rituals were obviously performed, often with great emphasis, ${ }^{55}$ but they were not the object of major concrete commemoration. Some specific war rituals do however appear in great numbers on painted vases which were used at the symposion and therefore display the social ideals of their users, the upper classes of polis citizens. The rituals chosen for representation are closely connected with the ideals of personal bravery in fighting. The focus of attention is not on the glory of victory but on the valour of manhood. The crucial narrative, represented on hundreds of vases, is not the glorious return of victors, but, surprisingly, the departure of young warriors for battle. They are shown putting on their armour, performing sacrifices, exploring their destiny in a victim's liver, and so showing their readiness to sacrifice themselves for their community (Pl. VII, I ). ${ }^{56}$ The community is represented by their fathers and wives. The fathers are the older generation, and their wives are the social counterpart of the male warrior. The oikos, the basic unit of the polis, depends on the warrior's arete.

After the battle the most common theme, even more surprisingly, is the rescue of fallen warriors. The virtue displayed is not the loyal concern of the survivors but the glorious self-sacrifice for the community on the part of the fallen, 'la belle mort'. ${ }^{57}$ Similarly in battles of Greek heroes against Amazons or even against centaurs, in which all Greek viewers sided with their mythical compatriots, not all Greeks are shown in a superior position; instead they show some clearly on the defensive and in heroic defeat. ${ }^{58}$ There are probably not many traditional societies to be found in world history in which the measure of warrior prestige was not actual victory but ideological valour, not the result of the warrior's action but the quality and spirit of his person. Such were the ideal values of warrior citizens, conceived from the perspective of the oikos, as they are represented on painted vases.

In public monuments on the other hand quite different ideals are evoked. Grave reliefs of fallen warriors, both from collective state graves and from individual tombs, show the deceased in glorious superiority defeating helpless adversaries. ${ }^{59}$ Warrior arete was therefore not represented in any fixed scheme. It appears in different, complementary forms, according to the particular social situations in which warrior virtues were celebrated.

Roman war rituals lead us into another world. They are almost never represented in the arts of the private sphere but appear almost exclusively on public monuments. In imperial Rome wars were fought not by upper class citizens but by professional troops commanded by Roman generals and officers, so that war was not a social and cultural experience but a matter for the state. As a result Romans do not much care for their fallen dead, because death in war - except for some great heroes of the past - was not glorious but shameful. Only victories counted. ${ }^{60}$ While war rituals in archaic and

${ }^{55}$ Pritchett, op. cit. (n. 54); A. Brelich, Guerre, agoni e culti nella Grecia arcaica (1961); R. Lonis, Guèrre et religion en grèce à l'époque classique (1979); M. H. Jameson, 'Sacrifice before battle', in V. D. Hanson, Hoplites. The Classical Greek Battle Experience ( $199 \mathrm{I}$ ), 197-227. See Cartledge, op. cit. (n. 7), 697: ‘... i Greci sembrano aver spinto la ritualizzazione oplitica all'estremo, sia sul campo di battaglia sia fuori.

${ }^{56} \mathrm{~F}$. Lissarrague, 'Autour du guerrier', in C. Bérard and J.-P. Vernant (eds), La cité des images (1984), 35-48, esp. 4I-6; idem, L'autre guerrier (I990), 35-69; A. B. Spiess, Der Kriegerabschied auf attischen Vasen der archaischen Zeit (1992).

${ }^{57}$ Lissarrague, op. cit. (n. 56,1984 ), 46-7; Lissarrague, op. cit. (n. 56, 1990), 71-96. Generally, J.-P. Vernant, 'La belle mort et le cadavre outragé', in G. Gnoli and J.-P. Vernant (eds), La mort, les morts dans les sociétés anciennes ( 1982$), 45-76$; C. W. Müller, 'Der schöne Tod des Polisbürgers', Gymnasium 96 (1989), 317-40.

58 Amazons: $L I M C$ I (1981), Amazones nos 6, 9, 12, $18,23,69$, etc. (e.g. west metopes of Parthenon) Centaurs: above all, the Kaineus episode. Further, e.g., south metopes of Parthenon.

59 Boardman, op. cit. (n. 29), figs 120-1, 153; Hölscher, op. cit. (n. ro), roz-I I; R. Stupperich, Staatsbegräbnis und Privatgrabmal (1977), 14-22. Cf. Lissarrague, op. cit. (n. 56, 1990), 75, on a hydria in München, fig. 75, where the deceased warrior appears in two different aspects, as a 'beau mort', carried by a companion, and as a forceful fighter, in the form of his psyche.

${ }_{60}$ Rüpke, op. cit. (n. 54), 248-9. 
classical Greece were closely focused on the social values of bravery and on the fight itself, Rome developed a much larger system of war rituals within which fighting and battles were presented as merely one aspect among many others.

Roman war rituals ${ }^{61}$ were much concerned with space, time, and the community. They defined the spaces of war and of peace, the times of beginning and ending wars, and the community of those who participate in war and those who do not. Another concern was with the emotional and ideological superstructure of war.

Such ideological rituals became a favourite theme of state monuments in the imperial period. The most complete range of such scenes is represented on the wellknown series of 'Aurelian' reliefs - originally from an arch of Marcus Aurelius, most of them re-used in the Arch of Constantine, others displayed in the Palazzo dei Conservatori. ${ }^{62}$ They celebrate the victorious war of Marcus Aurelius against the Marcomanni in a surprisingly unwarlike way. The whole war is depicted as a series of ritual acts that exemplify a whole range of significant imperial virtues. The series starts with a ceremonial departure from Rome, a profectio, that demonstrates the emperor's virtus. This is followed by a ritual purification of the army, a lustratio, exemplifying the commander's pietas and religious providentia; then by a speech to his troops, adlocutio, proving his good relations, concordia and fides, with his soldiers. The war itself is not depicted by any scene of battle or fighting. Instead we find scenes of voluntary or forced subjugation of enemies that demonstrate the emperor's clementia and iustitia, and a scene of the appointment of a client king, showing the emperor's political providentia. At the end of the campaign, we see the emperor's glorious return to Rome, his adventus (Pl. VII, 2), followed by his triumph, a final sacrifice to Jupiter, and the distribution of money from the war booty. These scenes display the emperor's virtus and felicitas, his pietas and liberalitas. The series transcends the reality and ideology of fighting: war becomes in this perspective a ritual system which makes visible an ideological system the system of virtues that sustain the Roman world empire. ${ }^{63}$

\section{Public Memory and Symbolic Conversion}

War monuments that perpetuate victory and glory are another means of converting military achievement into political power. Public monuments of a political character had their origins in Greece around 500 B.C. ${ }^{64}$ They effectively created a new patriotic identity and self-definition of Greek states, and for us they are important witnesses of this phenomenon. In Athens early examples of the monumentalization of public memory and political identity are the statue group of the Tyrannicides and the 'painted hall', stoa poikile, with a cycle of paintings describing glorious achievements of the polis, including the Battle of Marathon. ${ }^{65}$

Such monuments glorified individual political protagonists or the whole body of citizens, and the practice remained current throughout and beyond antiquity. As well as the representation of concrete political actors and actions, an iconography of allegorical and symbolic character was also soon created. Allegorical iconography was especially suited to complex ideological messages, and was created and deployed above all by states with strong and far-reaching political claims. It is probably not by chance that the relief parapet around the temple of Athena Nike in Athens, a victory temple erected in the later fifth century B.C. when Athens reached the peak of her political self-confidence, is

\footnotetext{
${ }^{61}$ Rüpke, op. cit. (n. 54), passim.

${ }^{62}$ I. S. Ryberg, Panel Reliefs of Marcus Aurelius (1967); Andreae, op. cit. (n. 19), Abb. 523-33.

${ }_{63}$ T. Hölscher, 'Die Geschichtsauffassung in der römischen Repräsentationskunst', $7 d I 95$ (1980), 265-321. Italian translation in T. Hölscher, Monumenti statali e pubblico (1993), 90-136.
}

${ }^{64}$ Hölscher, op. cit. (n. 1 5).

${ }_{65}$ Tyrant-slayers: S. Brunnsaker, The Tyrant-slayers of Kritios and Nesiotes (1971); B. Fehr, Die Tyrannentöter (1984); M. W. Taylor, The Tyrant Slayers (2nd edn, r99r). Stoa poikile: Hölscher, op. cit. (n. ro) 50-84; F. de Angelis, 'La battaglia di Maratona nella Stoa Poikile', AnnPisa ser. IV, I I (1996), I I 9-7I. 
the first example of emphatic political allegory in art. ${ }^{66}$ The parapet frieze represents a large number of Nikai or victory goddesses who are engaged in performing sacrifices, celebrating a magnificent victory festival in the presence of the city-goddess Athena, and erecting trophies from Athenian victories over both Greek and barbarian enemies. In this context, a group of relief bases belonging to some kind of victory monuments of the late fifth century B.C. is even more striking. The bases show Nikai adorning trophies and, most astonishing, captives seated on a pile of armour at the foot of a trophy, which are strongly reminiscent of well-known figure schemes in Roman triumphal art. ${ }^{67}$ This was a new iconographical language designed to articulate Athens' claim to a predominant political position in Greece.

Hellenistic kings took up and exploited these possibilities, ${ }^{68}$ but it was in late republican and imperial Rome that the art of political allegory and symbol reached its most developed form. The Augustan period, when some of the most impressive iconography of political dominion was created, was particularly influential. The range of possibilities was wide. On the one hand there are compositions of extraordinary complexity, such as that on the Gemma Augustea (Pl. VI, 2). ${ }^{69}$ In the upper register Augustus appears with the eagle of Jupiter, the highest state god, and with the capricorn, his birth sign. He is accompanied by Roma, the personification of the traditional Roman state, and surrounded by Tellus, the goddess of earth, and figures representing probably Kronos, the god of the golden age, and Oikoumene, the goddess of the inhabited world. Opposite stands Tiberius the commander of the army in the name of Augustus. This configuration assumes and represents the political theory of imperium maius, that is, of the emperor's supreme command and the executive role of his generals. Between stands a young prince who represents the principle of dynastic succession. This is an allegorical composition that combines the most important elements of imperial rule based on victory and universal dominion. On the other hand, there are also new, much simpler, motifs of a more succinct expressive character. A good example is the famous statue of Victoria on the globe which was erected in the Senate house as a symbol of universal Roman rule. $^{70}$

Taken together, the instances of monumental and symbolic conversion of military victory into political power constituted a huge enterprise in Roman culture and art. It was a practice based on Greek foundations but which was more fully developed under the Roman Empire. The increased quantity and elaboration corresponded to the greater needs of the Roman emperors and their greater claims to world rule.

\section{EPILOGUE: IDEOLOGICAL RULE}

Max Weber, in a famous and influential essay, distinguished three fundamental types of legitimate rule: ${ }^{71}$ traditional rule, based on dynastic inheritance; legal or bureaucratic rule, based on a professional class of state employees; and charismatic rule, based on the personal qualities and achievements of a political leader. In these terms, the rule of the Roman emperor was founded by Augustus on the basis of charismatic power and assumed in the course of time elements of both traditional, dynastic rule and, to a lesser degree, bureaucratic power. A fourth type, however, should be added to Weber's list, namely power and rule on the basis of political ideology. Writing in the

\footnotetext{
${ }^{66}$ T. Hölscher, 'Ritual und Bildsprache. Zur Deutung der Reliefs an der Brüstung um das Heiligtum der Athena Nike', $A M$ I 12 (1997), 143-66; M. S. Brouskari, To thorakio tou naou tes Athenas Nikes, ArchEph 137 (1998).

${ }^{67}$ J. Dörig, 'Une nouvelle base commémorant une victoire de la fin du Vème siècle av. J.-C.', in Zur griechischen Kunst, Antike Kunst, 9. Beiheft, (1972), 9-14.

${ }^{68}$ e.g. Tyche of Antiochia: T. Dohrn, Die Tyche von
}

Antiochia (1960); Smith, op. cit. (n. 36), 76, fig. 91 . Tazza Farnese: J. J. Pollitt, Art in the Hellenistic Age (1986), 257-9, fig. 279.

69 supra, n. 50 .

70 T. Hölscher, Victoria Romana (1967), 6-17.

${ }^{71} \mathrm{M}$. Weber, 'Die drei Typen der legitimen Herrschaft', in M. Weber, Gesammelte Aufsätze zur Wissenschaftslehre (Ist edn, I922; 4th edn, 1973), 475-88. See further, T. Hölscher in a forthcoming article, above n. 53 . 
early 1920 , at the very beginning of the great systems of state ideology of the twentieth century, Weber may have under-rated the legitimizing force of political ideologies.

Roman state ideology, which was focused on military success and on such qualities as concordia, virtus, honos, fides, clementia, and salus, was originally a collective ideology of the leading political class. Therefore control through ideology could be subsumed under the category of charismatic rule. But there are two reasons for taking ideological rule as an autonomous category.

Firstly, the Roman system of political values was not based around this or that individual emperor. It had been developed under the Roman Republic as a collective ideology of the political élite, and was later transferred as a clearly defined system of normative ideals to all Roman emperors. ${ }^{72}$ Individual emperors were expected to embody these ideals in a uniform way, with only slight personal variants. Members of the political élite followed their example. This collective state ideology thus transcends the type of an individual charismatic ruler such as Alexander the Great.

Secondly, as far as war is concerned, the Roman state ideology coincided with a number of phenomena which have little to do with individual charisma - specific conceptions of the body, of acting and interacting, of the self and the other, and of killing and dying, whose visual expressions have been investigated here. They show how strongly the Roman ideology of world empire changed ideas of war and power and introduced a different type of political rule.

Such theoretical considerations stand far from the real experiences of war. Nevertheless, even the highly ideological composition of the Gemma Augustea (P1. VI, 2) presents not only the leading ideas of Roman imperial power in the upper register but also in the lower zone the destiny of the vanquished enemies. This brings to mind the aphorism of Stanislaw Jerzy Lec: 'In the struggle of ideologies the victims are men' ${ }^{73}$

\section{German Archaeological Institute, Rome}

thoelsch@vatlib.it

\footnotetext{
${ }^{72} \mathrm{~T}$. Hölscher, 'Die Anfänge der römischen Repräsentationskunst', $R M 85$ (1978), 315-57; K.-J. Hölkeskamp, Die Entstehung der Nobilität (1987), 204-40.

${ }^{73}$ This article was completed during my stay as a
}

research professor at the German Archaeological Institute in Rome for a project, 'BilderweltLebenswelt im antiken Rom und im Römische Reich', financed by the Gerda Henkel Stiftung, Düsseldorf. 